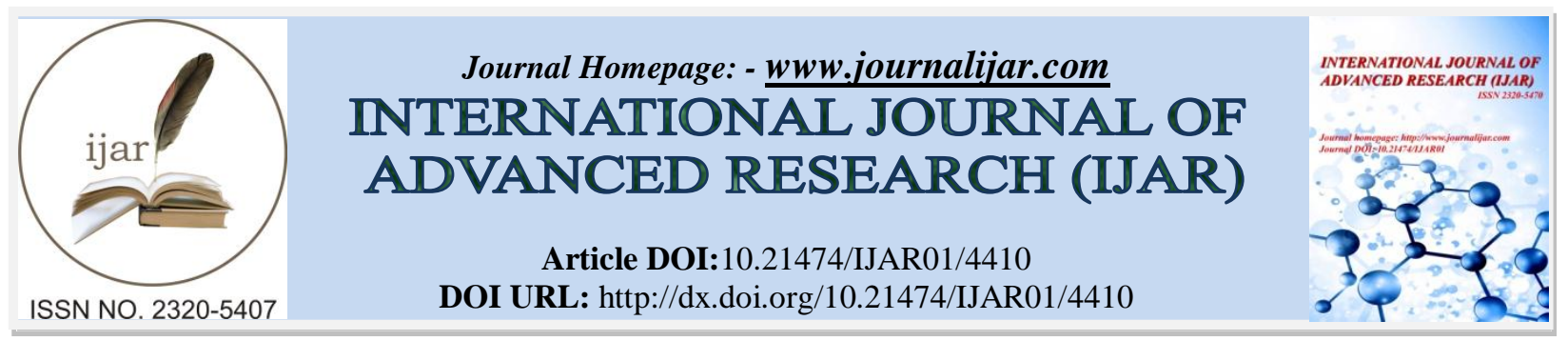

RESEARCH ARTICLE

\title{
FINANCIAL PERFORMANCE REVIEW OF "HIMACHAL ROAD TRANSPORT CORPORATION LTD” WITH SPECIAL REFERENCE TO SHIMLA DIVISION.
}

\author{
Dhanisha Negi ${ }^{1}$ and Sunil Kumar Gupta ${ }^{2}$. \\ 1. Research scholar (Assistant Professor) Himachal Pradesh University, Shimla 171005. \\ 2. Professor in Department of Commerce, Himachal Pradesh University, Shimla 171005.
}

\section{Manuscript Info}

.........................

Manuscript History

Received: 07 April 2017

Final Accepted: 09 May 2017

Published: June 2017

Key words:-

Himachal Road Transport Corporation, Shimla Division, Service Sector,

Financial Performance, Financial losses, ratio analysis

\section{Abstract}

HRTC serves the role of lifeline across the state of Himachal Pradesh. It is only dependable mode of transportation in a state in absence of other mode of transportation. It is providing services in most of the rural areas of the state. The objective of present paper is to study the financial performance analysis of one of the largest division that is Shimla division of Himachal Road Transport Corporation Ltd. (HRTC) by using ratio analysis technique. Among the various financial techniques to analyze the performance of any business organization, the ratio analysis is most appropriate to evaluate the financial performance of the business concern, since it examines the performance of the business organization in different dimensions. Financial analysis of an organization provides the clear view of its performance parameters, present as well as past performance. It is helpful in assessing the corporate excellence, judging the credit worthiness, processing bond rating and assessing market risk. The study is based on secondary data collected from secondary sources. The major findings of the analysis are: The debt equity ratio has not maintained the standard norm during the study period, because of the higher proportions of debt and correspondingly the absence of capital contributions from the participating governments. Further, during the period of study, current ratio is not up to the mark.

Copy Right, IJAR, 2017,. All rights reserved.

\section{Introduction:-}

Transport plays a crucial role in the economic development of a nation and the social and cultural life of its people. If agriculture and industry are regarded as the body and the bones of the India economy, transport and communication are its nerves which help the mobilization and migration of men and materials. It is said that immobility creates poverty while mobility is an essential ingredient of progress. Transportation plays a special role in economic development by achieving various national goals, such as getting land into production, marketing of agricultural commodities, making forests and naturals wealth accessible for industry, expanding trade, planning and executing health and education programs and above all exchanging ideas. It is a well- established truth that development of a country is largely conditioned by the adequacy, efficiency, regularity, safety and punctuality of the transport system. Thus transport is regarded as civilization. 
Finance is regarded as the lifeblood of a business enterprise. In general, finance may be defined as a provision of money at the time it is wanted. Finance is required to aid in economic decision making, investment and finding decision-making. Analysis and Interpretation of financial statements are necessary to assess the financial performance, the profitability and financial soundness of the organization.

\section{HRTC:-}

In Himachal Pradesh public bus transport is managed by the Himachal Road Transport Corporation ltd (HRTC). It was set up in 2-10-1974 with the objective of providing adequate, efficient, economic and properly coordinated road transport services and with this Slogan - safe services, courteous services. For better management of public transport, HRTC is bifurcated into four division four viz. Dharamshala, Mandi, Hamirpur and Shimla. These four divisions are headed by four Divisional Managers. Following units are being controlled by these divisions. Under Dharamshala Divisions - There are 5 units named Dharamshala, Palmpur, Baijnath, Pathankot and Chamba. Mandi Division also has 5 units namely Kullu, Kelong, Mandi, Sarkaghat and Sunder-Nagar. Hamirpur division is controlling 5 units namely Bilaspur, Nalagarh, Una, Hamirpur and Dehra. Shimla Division is controlling 8 units and is one of the biggest divisions. These units are Shimla Local unit II, Shimla Rural Unit- Ill at Dhali, Shimla Taradevi Unit-I, Solan, Nahan, Rohru, Rampur and Recongpeo. In addition to this there are four workshops situated at Taradevi, Jassur, Panwanoo and Mandi. The workshops at Taradevi and Jassur are responsible for major overhauling of engines; fuel pumps assemblies etc. the workshop at Taradevi is also responsible for printing stocking and issue of ticket books to Regional offices. The workshops at Parwanoo, Jassure and Mandi are responsible for fabrication of bus bodies, tire retreading etc. The primary accounts are maintained by each divisional office, workshop units and rendered to Head office for consolidation. It has 7 driver training institutes. Figures are given in table 1

Table 1:- Network of Himachal Road Transport Corporation as on Dec 2016

\begin{tabular}{|l|c|}
\hline Depots & 27 \\
\hline Divisions & 4 \\
\hline Vehicles & 3153 \\
\hline Buses & $3012+48$ attached \\
\hline Coverage per day (Kms) & 4.59 lakhs \\
\hline Routes & 2530 \\
\hline Average traffic revenue per day & 162.00 lakhs \\
\hline Staff & 8619 \\
\hline Staff ratio per bus & 4.37 \\
\hline
\end{tabular}

\section{Source: hrtc.gov.in}

Need of the Study:-

Himachal Road Transport Corporation has played a pivotal role in the economic growth of the state through operating an extensive passenger transport network and reaching out to villages. HRTC is vigorously pursuing a process of technical and managerial up gradation. But, financial and passengers viability has become a critical goal, since last few years, the existence of such an ideal and progressive Government venture is striving to sustain. It is passing through the critical financial condition, and also it is suffering from huge amount of losses. Financial analysis is the process of identifying the financial strength and weakness of the firm by properly establishing relationship between the items of the balance sheet and profit and loss account. The present study is to measure the financial soundness and liquidity and solvency position of the concerned organization through financial statement of the organization. The users of financial information comprise owner, creditors, manager, employees, customer, suppliers, government and society are very much interested to know earning ability, liquidity and solvency position of the organization. So, it is the moral duty of government, management and employees of HRTC, and all public to improve the financial liquidity of the HRTC by reducing amount of losses. Various controllable and uncontrollable factors affect the profitability, liquidity and solvency of the HRTC. The profitability of HRTC is quite low and unsatisfactory so by controlling at least controllable factors HRTC can improve its financial position.

Objectives of the Study:-

The present study has been taken up with the following objectives 
1. To analyze the financial performance of Himachal road Transport Corporation Ltd., by Appling the technique of ratio analysis

2. To make suggestions to ensure financial performance by improving the functioning of the Himachal Road Transport Corporation ltd.

\section{Research Methodology:-}

The information which is needed for the study was collected through secondary data sources from the Corporation and the tools like ratio analysis are used. The tool is analyzed and interpreted in a perfect way. The study employs secondary data that are mainly available in published annual reports of Corporation. With the improvement of information technology, it was to collect required data through the online.

\section{Source of Data:-}

The data relating to the present study have been obtained from the annual accounts of the HRTC. In addition to this, literature pertaining to the HRTC such as their annual administration reports and articles on them published in various journals has been taken into consideration. Besides, supplementary data has been collected from various statements prepared by the unit of study. For a meaningful analysis, facts have also been collected from sources other than the above, such as from discussion with the employees of HRTC and other authorities concerned and experts on the subjects.

\section{Period of the Study:-}

The study covers the period of nine years between 2006-07 to 2014-15 for analyzing the financial statement such as income statements and balance sheet the Himachal Road transport corporation ltd. The scope of the study involves the various factors that affect the financial efficiency of the company. The performance is compared within those periods. It can improve to increase the efficiency of its assets and funds employed.

\section{Research Gap:-}

Many studies covered Himachal Road Transport Corporation but the present study attempt to study only the Shimla division which is largest one.

Tools used for Analysis:-

Ratio analysis is the only tool which is used in the present study. It is used to analyses the liquidity, solvency and profitability of Road Transport Corporation in Himachal.

\section{Analysis and Interpretation:-}

Ratio analysis:-

a. Liquidity: - liquidity expresses the capacity of the company to meet its short term obligations. Below two liquidity ratios are explained.

- Current ratio: Current ratio may be defined as the relationship between current assets and current liabilities. This ratio is also known as working capital ratio. It is calculated by dividing the total of current assets by total of the current liabilities. Current assets include inventories, cash and bank balances, loans and advances, etc., Current liabilities include sundry creditors, and advances received provisions and other liabilities.

\section{Current ratio $=$ Current assets /Current liability}

Below table shows the current ratio of corporation during study period

Table 2:- Current Ratio

\begin{tabular}{|l|l|l|l|l|l|l|l|l|l|l|}
\hline Divisions & $\begin{array}{l}\mathbf{2 0 0 6 -} \\
\mathbf{0 7}\end{array}$ & $\begin{array}{l}\mathbf{2 0 0 7 -} \\
\mathbf{0 8}\end{array}$ & $\begin{array}{l}\mathbf{2 0 0 8} \\
\mathbf{0 9}\end{array}$ & $\begin{array}{l}\mathbf{2 0 0 9}- \\
\mathbf{1 0}\end{array}$ & $\begin{array}{l}\mathbf{2 0 1 0}- \\
\mathbf{1 1}\end{array}$ & $\begin{array}{l}\mathbf{2 0 1 1 -} \\
\mathbf{1 2}\end{array}$ & $\begin{array}{l}\mathbf{2 0 1 2}- \\
\mathbf{1 3}\end{array}$ & $\begin{array}{l}\mathbf{2 0 1 3}- \\
\mathbf{1 4}\end{array}$ & $\begin{array}{l}\mathbf{2 0 1 4 -} \\
\mathbf{1 5}\end{array}$ & $\begin{array}{l}\text { Averag } \\
\text { e }\end{array}$ \\
\hline Local Unit & 0.8399 & 1.1541 & 0.6047 & 0.6537 & 0.4401 & 0.3035 & 0.2327 & 0.0503 & 0.1464 & 0.4917 \\
\hline Nahan & 1.0614 & 1.1260 & 0.8822 & 0.9250 & 1.7087 & 1.0309 & 0.7744 & 0.0786 & 0.2188 & 0.8673 \\
\hline Rampur & 1.0852 & 5.9615 & 1.1404 & 1.6057 & 0.6132 & 0.3461 & 0.2577 & 0.0525 & 0.1158 & 1.2420 \\
\hline $\begin{array}{l}\text { Reckong } \\
\text { Peo }\end{array}$ & 0.2827 & 0.2900 & 0.2098 & 0.2763 & 0.1578 & 0.0864 & 0.0939 & 0.0580 & 0.0807 & \\
\hline
\end{tabular}




\begin{tabular}{|l|l|l|l|l|l|l|l|l|l|l|}
\hline Rohroo & 0.3612 & 0.2758 & 0.2531 & 0.2864 & 0.2543 & 0.1741 & 0.1487 & 0.0790 & 0.1387 & 0.2190 \\
\hline Rural Unit & 0.5553 & 1.0033 & 0.2723 & 0.5156 & 0.2199 & 0.2356 & 0.1406 & 0.0955 & 0.0807 & 0.3465 \\
\hline Solan & 1.0762 & 1.1961 & 0.7104 & 0.5563 & 0.2665 & 0.2330 & 0.1812 & 0.0799 & 0.1198 & 0.4911 \\
\hline Taradevi & 1.7454 & 2.3153 & 0.6427 & 1.0571 & 0.5156 & 0.2973 & 0.1874 & 0.0172 & 0.0265 & 0.7560 \\
\hline
\end{tabular}

(Source: Annual Reports of HRTC from the year 2006-07 to 2014-15)

The current ratio of selected divisions are shown in table 2 the current ratio of local unit shows the decreasing and fluctuating trend during the study period following the other divisions of HRTC except the Rampur division. Rampur divisions average ratio is 1.2420 which is good, the ratio of Rampur division ranged between 0.2577 in 2012- 2013 and 5.9615 with decreasing trend during the study period. The current ratio of Rekong Peo division is stable in the initial years then goes on fluctuating which shows the average ratio 0.1706 which is unsatisfactorily eventually all divisions are showing ratios which are not up to the standards because divisions are not maintaining the standard ratio of 2:1.

- Liquid Ratio: This ratio is also known as acid test or quick ratio and is another widely used device for judgment of true short-term solvency of a business. This ratio establishes a relationship between the quick assets (liquid assets) and current liabilities of a firm. Liquid assets for accounting purpose include all current assets except stock and prepaid expenses. It may be expressed as:

Liquid Ratio $=\quad$ Liquid Assets $/$ Current Liabilities

A quick ratio of 1:1 is the standard norm for evaluating the accuracy of the information pertaining to going concern solvency of a business. Table 3 presents liquid ratio pertaining to the HRTC Corporation during the study period.

Table 3:- (Quick ratio) Liquidity Ratio

\begin{tabular}{|l|l|l|l|l|l|l|l|l|l|l|}
\hline Divisions & $\begin{array}{l}\mathbf{2 0 0 6 -} \\
\mathbf{0 7}\end{array}$ & $\begin{array}{l}\mathbf{2 0 0 7 -} \\
\mathbf{0 8}\end{array}$ & $\begin{array}{l}\mathbf{2 0 0 8} \\
\mathbf{0 9}\end{array}$ & $\begin{array}{l}\mathbf{2 0 0 9}- \\
\mathbf{1 0}\end{array}$ & $\begin{array}{l}\mathbf{2 0 1 0 -} \\
\mathbf{1 1}\end{array}$ & $\begin{array}{l}\mathbf{2 0 1 1 -} \\
\mathbf{1 2}\end{array}$ & $\begin{array}{l}\mathbf{2 0 1 2 -} \\
\mathbf{1 3}\end{array}$ & $\begin{array}{l}\mathbf{2 0 1 3} \\
\mathbf{1 4}\end{array}$ & $\begin{array}{l}\mathbf{2 0 1 4 -} \\
\mathbf{1 5}\end{array}$ & $\begin{array}{l}\text { Averag } \\
\text { e }\end{array}$ \\
\hline Local Unit & 0.8352 & 0.8799 & 0.4917 & 0.4816 & 0.3090 & 0.2102 & 0.1617 & 0.0005 & 0.0002 & 0.3744 \\
\hline Nahan & 0.9749 & 1.0187 & 0.8295 & 0.8318 & 1.5610 & 0.9256 & 0.6664 & 0.0294 & 0.0130 & 0.7611 \\
\hline Rampur & 0.9843 & 4.9263 & 0.8792 & 1.2435 & 0.4413 & 0.2386 & 0.1760 & 0.0010 & 0.0007 & 0.9879 \\
\hline $\begin{array}{l}\text { Reckong } \\
\text { Peo }\end{array}$ & 0.0315 & 0.0200 & 0.0207 & 0.0064 & 0.0097 & 0.0026 & 0.0099 & 0.0059 & 0.0034 & \\
\hline Rohroo & 0.0203 & 0.0273 & 0.0151 & 0.0173 & 0.0155 & 0.0104 & 0.0077 & 0.0111 & 0.0005 & 0.0139 \\
\hline Rural Unit & 0.0503 & 0.1012 & 0.0380 & 0.0592 & 0.0133 & 0.0087 & 0.0056 & 0.0054 & 0.0029 & 0.0316 \\
\hline Solan & 0.2847 & 0.0318 & 0.0093 & 0.0032 & 0.0039 & 0.0003 & 0.0007 & 0.0096 & 0.0043 & 0.0387 \\
\hline Taradevi & 1.3352 & 1.6191 & 0.5854 & 0.7107 & 0.4814 & 0.2257 & 0.1521 & 0.0016 & 0.0009 & 0.5680 \\
\hline
\end{tabular}

Source: annual reports and accounts from 2006 to 2014

The quick ratio of local unit manifested in the above table no 3 is showing decreasing trend during the research period. The ratio was 0.83 and 0.87 times in 2006-2008 then declined to approx 0.49 in 2008 to 2010, after financial year 2010-2011 goes on decreasing with great fluctuation, in the last year the ratio was 0.002 with an average of 0.37 times which could not maintain quick ratio according to norms. The quick ratio of Rampur, Rekong Peo, Rohroo, Rural unit and Solan, Tara devi was fluctuating in the year of 2006-2007 all the units were having less than 1 ratio except Tara Devi having 1.3352 times, but in the year of 2007-2008 the quick ratio of Nahan (1.0187), Rampur (4.9263), and Tara Devi,s quick ratio is went up (1.3352) which helps to maintain the standard ratio that is 1:1. Eventually the ratio in all the years of study period during 2006-2007 and 2013-2014 found less than the norms of 1:1. Therefore the corporation is advised to tighten to its credit policy.

Solvency ratio:-

Solvency ratios measure a company's ability to meet long term obligations. In simple terms, it provides information on how much debt the company has taken and if it is profitable enough to pay the interest on debt in the long term. Below two ratio of solvency are given. 
Debt-equity Ratio:-This ratio also called as 'External -Internal Equity ratio'. It mainly calculated to assess the soundness of long term financial policies and to determine the stakes of outsiders and owners. It determines the relationship between debt and equity. It computed by following formula

\section{Debt-Equity ratio = Internal fund / External fund}

Table 4:- Debt-Equity Ratio

\begin{tabular}{|l|l|l|l|l|l|l|l|l|l|l|}
\hline Divisions & $\begin{array}{l}\mathbf{2 0 0 6 -} \\
\mathbf{0 7}\end{array}$ & $\begin{array}{l}\mathbf{2 0 0 7 -} \\
\mathbf{0 8}\end{array}$ & $\begin{array}{l}\mathbf{2 0 0 8 -} \\
\mathbf{0 9}\end{array}$ & $\begin{array}{l}\mathbf{2 0 0 9} \\
\mathbf{1 0}\end{array}$ & $\begin{array}{l}\mathbf{2 0 1 0 -} \\
\mathbf{1 1}\end{array}$ & $\begin{array}{l}\mathbf{2 0 1 1 -} \\
\mathbf{1 2}\end{array}$ & $\begin{array}{l}\mathbf{2 0 1 2 -} \\
\mathbf{1 3}\end{array}$ & $\begin{array}{l}\mathbf{2 0 1 3 -} \\
\mathbf{1 4}\end{array}$ & $\begin{array}{l}\mathbf{2 0 1 4 -} \\
\mathbf{1 5}\end{array}$ & $\begin{array}{l}\text { Averag } \\
\text { e }\end{array}$ \\
\hline Local Unit & 0.0354 & 0.0316 & 0.0342 & 0.0279 & 0.0490 & 0.0440 & 0.0420 & 0.0388 & 0.0843 & 0.0430 \\
\hline Nahan & 0.2524 & 0.1954 & 0.0874 & 0.0897 & 0.1338 & 0.1841 & 0.2182 & 0.2177 & 0.4190 & 0.1997 \\
\hline Rampur & 1.1495 & 0.2671 & 0.3481 & 0.4954 & 2.0818 & -0.6971 & -0.6197 & -0.4119 & -0.6195 & 0.2215 \\
\hline $\begin{array}{l}\text { Reckong } \\
\text { Peo }\end{array}$ & 0.1101 & 0.1029 & 0.1274 & 0.1942 & 1.5115 & -0.2192 & -0.1690 & -0.1245 & -0.1194 & \\
\hline Rohroo & 0.0704 & 0.0494 & 0.0393 & 0.0303 & 0.0421 & 0.0461 & 0.0444 & 0.0391 & 0.0666 & 0.0475 \\
\hline Rural Unit & 0.0737 & 0.0435 & 0.0515 & 0.0411 & 0.0679 & 0.0570 & 0.0674 & 0.0576 & 0.0994 & 0.0621 \\
\hline Solan & 0.0476 & 0.0488 & 0.0426 & 0.0405 & 0.0480 & 0.0563 & 0.0664 & 0.0609 & 0.1083 & 0.0577 \\
\hline Taradevi & 0.0348 & 0.0245 & 0.0285 & 0.0247 & na & 0.0384 & 0.0458 & 0.0419 & 0.0583 & 0.0371 \\
\hline
\end{tabular}

Source: annual reports and accounts from 2006 to 2014

The table no 4 debt equity ratio of local unit reveals fluctuating trend. The lowest is 0.0279 in the year of 2009 2010 and went up to 0.0843 in the year 2013-2014 with an average of 0.0430. Debt equity ratio of Rampur division is fluctuating positively from 2006-2007 t0 2011-2012 the highest is in 2006-2007 that is 1.1495, after 2010-2011 the ratio is fluctuating negatively with an average of 0.2215 . The debt equity ratio of Reckong Peo division is positive till 2010 and then it becomes negative. The table shows except Nahan and Reckon Peo division other divisions never became negative in the study period. There are not so fluctuations in other divisions. Above table showed that debt equity ratio of HRTC ltd is downward. So corporation is advised not to reduce the ratio to maintain standard otherwise corporation will become insolvent.

\section{Propriety Ratio:-}

This ratio establishes a relationship between Net worth and Tangible Assets. This ratio is also known as Net Worth to Total Assets or Shareholders Equities to Total Equities ratio and Equities Ratio. It expresses the relationship between net worth and total assets. This ratio can be expressed as:

Propriety ratio $=$ Net worth $/$ Total assets

Whereas Net worth = Equity share capital + Preference Share Capital + Reserves - Fictitious Asset

Total asset $=$ Fixed Asset + current asset (excluding fictitious assets) Reserves earmarked especially for a particular purpose should not be included in calculation of Net worth. Table 5 shows the proprietary ratio in selected divisions from 2006-2007 to 2014-15

Table 5:- Proprietary Ratio of HRTC

\begin{tabular}{|l|l|l|l|l|l|l|l|l|l|l|}
\hline Divisions & $\begin{array}{l}\mathbf{2 0 0 6 -} \\
\mathbf{0 7}\end{array}$ & $\begin{array}{l}\mathbf{2 0 0 7}- \\
\mathbf{0 8}\end{array}$ & $\begin{array}{l}\mathbf{2 0 0 8}- \\
\mathbf{0 9}\end{array}$ & $\begin{array}{l}\mathbf{2 0 0 9}- \\
\mathbf{1 0}\end{array}$ & $\begin{array}{l}\mathbf{2 0 1 0} \\
\mathbf{1 1}\end{array}$ & $\begin{array}{l}\mathbf{2 0 1 1 -} \\
\mathbf{1 2}\end{array}$ & $\begin{array}{l}\mathbf{2 0 1 2} \\
\mathbf{1 3}\end{array}$ & $\begin{array}{l}\mathbf{2 0 1 3}- \\
\mathbf{1 4}\end{array}$ & $\begin{array}{l}\mathbf{2 0 1 4} \\
\mathbf{1 5}\end{array}$ & $\begin{array}{l}\text { Averag } \\
\text { e }\end{array}$ \\
\hline Local Unit & -0.2947 & -0.1941 & -0.2272 & -0.1762 & -0.1047 & -0.0225 & 0.3641 & 0.3718 & -0.2548 & -0.0598 \\
\hline Nahan & 0.0850 & 0.1329 & 0.0304 & 0.1407 & 0.0385 & 0.1393 & 1.2815 & 1.0386 & 0.0634 & 0.3278 \\
\hline Rampur & 0.0118 & -0.0257 & 0.0591 & 0.1551 & 0.1585 & 0.2603 & 1.3310 & 1.1426 & 0.1034 & 0.3551 \\
\hline $\begin{array}{l}\text { Reckong } \\
\text { Peo }\end{array}$ & 0.0637 & 0.1775 & 0.2589 & 0.3254 & 0.3400 & 0.4515 & 1.7246 & 1.4606 & 0.2192 & \\
\hline Rohroo & -0.1597 & -0.1260 & -0.1671 & -0.1167 & -0.1841 & -0.0970 & 0.6834 & 0.5491 & -0.2059 & 0.0196 \\
\hline Rural Unit & -0.1782 & -0.1680 & -0.2738 & -0.2604 & -0.2212 & -0.0552 & 0.5408 & 0.4586 & -0.2904 & -0.0498 \\
\hline Solan & -0.1609 & -0.1168 & -0.1416 & -0.1442 & -0.0950 & 0.0627 & 0.9017 & 0.7457 & -0.0434 & 0.1120 \\
\hline Taradevi & -0.1698 & -0.1986 & -0.2156 & -0.1611 & -0.1984 & -0.0849 & -0.2824 & -0.2343 & -0.1044 & -0.1833 \\
\hline
\end{tabular}

Source: annual reports and accounts from 2006-2007 to 2014-2015 
The above Table No.5 showed the ratio of rerun on net worth of HRTCL which also indicated fluctuated trend. The highest average ratio had been found of 0.5979 of Reckong Peo Division and the lowest ratio had also been found of -0.02534 of Rampur division. The ratio was not quite satisfactory. The ratio of return on net worth of HRTC was seen in above Table No. 1.6. The ratio explained the down ward trend. The table shows that only the Reckong Peo division whose proprietary ratio never become negative this division shows highest ratio 1.7246 in the year 2011 2012. The ratio of Tara Devi Division is negative during the study period showing the worst return on net worth ratio. The ratio has been highly dissatisfactory during the study period.

\section{Profitability Ratios:-}

Profit is an excess of revenues over associated expenses for an activity over a period of time. Terms with similar meanings include 'earnings', 'income', and 'margin'. It is the index to the economic progress, improved national income and rising standard of living. Profitability ratios measure a firm's ability to generate profits. There are two types of profitability ratios, are explained:

\section{Return on capital employed:-}

Return on capital employed shows the efficiency of the firm and the ratio is calculated for a period of 9 years and shown in table 6 for analysis.

Table 6:- Return on capital employed

\begin{tabular}{|c|l|l|l|l|l|l|l|l|l|l|}
\hline Divisions & $\begin{array}{l}\mathbf{2 0 0 6}- \\
\mathbf{0 7}\end{array}$ & $\begin{array}{l}\mathbf{2 0 0 7}- \\
\mathbf{0 8}\end{array}$ & $\begin{array}{l}\mathbf{2 0 0 8}- \\
\mathbf{0 9}\end{array}$ & $\begin{array}{l}\mathbf{2 0 0 9}- \\
\mathbf{1 0}\end{array}$ & $\begin{array}{l}\mathbf{2 0 1 0}- \\
\mathbf{1 1}\end{array}$ & $\begin{array}{l}\mathbf{2 0 1 1}- \\
\mathbf{1 2}\end{array}$ & $\begin{array}{l}\mathbf{2 0 1 2}- \\
\mathbf{1 3}\end{array}$ & $\begin{array}{l}\mathbf{2 0 1 3}- \\
\mathbf{1 4}\end{array}$ & $\begin{array}{l}\mathbf{2 0 1 4 -} \\
\mathbf{1 5}\end{array}$ & $\begin{array}{l}\text { averag } \\
\text { e }\end{array}$ \\
\hline Local Unit & -0.2887 & -0.1848 & -0.2066 & -0.1386 & -0.0958 & -0.0211 & 0.4164 & 0.8613 & -0.2694 & 0.0081 \\
\hline Nahan & 0.1184 & 0.1666 & 0.0379 & 0.1842 & 0.0425 & 0.1871 & 2.0771 & 2.3522 & 0.1433 & 0.5899 \\
\hline Rampur & 0.0145 & -0.0295 & 0.0651 & 0.1759 & 0.1924 & 0.3760 & 2.2190 & 2.3968 & 0.2047 & 0.6239 \\
\hline $\begin{array}{c}\text { Reckong } \\
\text { Peo }\end{array}$ & 0.0684 & 0.1960 & 0.2752 & 0.3851 & 0.3859 & 0.6640 & 3.0728 & 3.0244 & 0.5017 & \\
\hline Rohroo & -0.1920 & -0.1500 & -0.1838 & -0.1321 & -0.2151 & -0.1212 & 0.9962 & 0.9564 & -0.3462 & 0.0680 \\
\hline Rural Unit & -0.2406 & -0.2171 & -0.3396 & -0.3381 & -0.2906 & -0.0688 & 1.0068 & 0.9782 & -0.5694 & -0.0088 \\
\hline Solan & -0.1794 & -0.1291 & -0.1472 & -0.1459 & -0.1044 & 0.0786 & 1.3438 & 1.3218 & -0.0798 & 0.2176 \\
\hline Taradevi & -0.2019 & -0.2359 & -0.2645 & -0.1817 & -0.2361 & -0.1136 & -0.4379 & -0.4405 & -0.1872 & -0.2555 \\
\hline
\end{tabular}

\section{Source: annual reports and accounts from 2006 to 2014}

The Return on Capital Employed Ratio of HRTC has been presented in the Table No 6. In HRTC, the Return on Capital Employed Ratio shows Fluctuating trend. It ranged between 3.0728 per cent in the year 2013-14 and -0.4405 per cent in the year 2013-14 with a maximum average ratio of 0.9526 per cent. The Tara Devi division of HRTC is showing negative trend throughout the study period in 2006-2007 the ratio is -0.2019 and becomes -0.4405 in 2013 showing negative trend. The ratio of Reckong Peo division of HRTC ranged 0.0684 to 3.0728 during the study period. In the year 2012-2013 all division are showing positive trend on return on capital employed except the Tara Devi division.

\section{Return on Asset ratio:-}

Return on Asset is measured as the ratio of profits generated to the total assets under the responsibility of management. The formula is given below.

\section{Return on Asset = Net Income /Total Assets}

The Returns on Assets of different divisions are shown in table 7.

Table 7:- Return on assets

\begin{tabular}{|c|c|c|c|c|c|c|c|c|c|c|}
\hline \multicolumn{11}{|c|}{ (Kato in mime) } \\
\hline Divisions & $\begin{array}{l}\text { 2006- } \\
07\end{array}$ & $\begin{array}{l}\text { 2007- } \\
08\end{array}$ & $\begin{array}{l}\text { 2008- } \\
09\end{array}$ & $\begin{array}{l}\text { 2009- } \\
10\end{array}$ & $\begin{array}{l}\text { 2010- } \\
11\end{array}$ & $\begin{array}{l}\text { 2011- } \\
12\end{array}$ & $\begin{array}{l}2012- \\
13\end{array}$ & $\begin{array}{l}\text { 2013- } \\
14\end{array}$ & $\begin{array}{l}2014- \\
15\end{array}$ & $\begin{array}{l}\text { averag } \\
\text { e }\end{array}$ \\
\hline Local Unit & 0.2046 & 0.2219 & 0.2491 & 0.2801 & 0.2506 & 0.2273 & 0.2317 & 0.1281 & 0.1913 & 0.2205 \\
\hline Nahan & 0.6404 & 0.6936 & 0.7483 & 0.8226 & 0.8150 & 0.9699 & 0.9750 & 0.9548 & 1.2136 & 0.8704 \\
\hline Rampur & 5.6004 & 2.7260 & 3.0936 & 3.8516 & $\begin{array}{l}14.041 \\
6\end{array}$ & -4.6836 & -3.7233 & -2.5648 & -2.6524 & 1.7432 \\
\hline Reckong & 0.7100 & 0.8712 & 1.2682 & 2.2719 & 14.926 & -1.8550 & -1.1127 & -0.9225 & -0.7472 & 1.7123 \\
\hline
\end{tabular}




\begin{tabular}{|l|l|l|l|l|l|l|l|l|l|l|}
\hline Peo & & & & & 8 & & & & & \\
\hline Rohroo & 0.3639 & 0.3600 & 0.3662 & 0.3454 & 0.3275 & 0.3304 & 0.3071 & 0.2955 & 0.3077 & 0.3337 \\
\hline Rural Unit & 0.3276 & 0.3130 & 0.3085 & 0.2780 & 0.2769 & 0.3252 & 0.2587 & 0.2465 & 0.2565 & 0.2879 \\
\hline Solan & 0.2915 & 0.3172 & 0.3250 & 0.3300 & 0.3167 & 0.3261 & 0.3053 & 0.3001 & 0.3117 & 0.3137 \\
\hline Taradevi & 0.2199 & 0.2213 & 0.2315 & 0.2197 & 0.2195 & 0.2255 & 0.2217 & 0.2201 & 0.2397 & 0.2243 \\
\hline
\end{tabular}

Source: annual reports and accounts from 2006-07 to 2014-15

An Inter division analysis shows that average return on assets of Rampur division (1.7432) is highest followed by Reckong Peo division (1.7123) and Nahan division (0.8704). Average return on assets of Local unit (0.2205) is lowest followed by Tara Devi Division (0.2243) and Rural Unit (0.2879). When a comparison of growth rate of different divisions are made, Rampur division is giving highest return on assets from the year 2006 to 2010, however from 2010 return goes on decreasing and the Tara devi Division is showing stable return throughout the study period There did not exists any significant inter division variation with respect to return on assets. It is further observe that growth rate of most divisions are negative

\section{Limitations of the Study:-}

The proposed study is bound to have a few limitations. This research work, as any other research work is also suffering from limitations. These limitations are identified below:

* The study is limited to a period of 9 years only.

* The study covers only one Division of HRTC ltd.

* Data of this study has been taken from published annual reports only. Therefore, how far the decisions taken on the basis of this information are correct depends upon the correctness and accuracy of this information

* The analysis of financial statements is based on secondary data so the limitations or shortcoming of secondary data affects the conclusion and results of the study.

* As the HRTC is State Level Public Sector Undertakings experienced delay in annual account reporting updated information could not be obtained.

* The study is subjected to general human limitations, such as time limitation, way of thinking etc.

* Obtaining information about every aspect becomes difficult. Financial analysis is related to other subject such as economic, statistics, management etc. The full benefits of financial analysis can only be derived when financial aspects are seen in relation with all these related subjects. But, it becomes very difficult to co-relate in the absence of data.

* Analysis of financial statements is based on some common techniques. And it is a universal fact that all techniques have their own pros \& cons and since this study is also based one of these techniques, so the techniques limitation may affect the result.

\section{Findings and Suggestions:-}

The following are the conclusions that can be observed from the capital structure of the HRTC.

* The debt equity ratio has not attained the standard norm of 2:1 during the study period, because of the higher proportions of debt and correspondingly the absence of capital contributions from the participating governments.

* The current ratio and quick ratio of the HRTC fluctuating all the time these ratios are less than the standard norms. This fluctuating trend in the concerned ratios reflects an unsatisfactory financial position.

Therefore it is mandatory that the corporation should maintains enough cash and bank balance which it can easily meet the working capital requirements and corporation should not depend heavily on outsiders fund.

\section{References:-}

1. Annual report of Himachal Road Transport Corporation from the year 2006-07 to 2014-15

2. Kothari C.R "Research Methodology- Mehtods \& Techniques", Revised 2nd Edition

3. Berwal Rohit "Analysis of Financial Structure of Rajasthan State Road Development \& Construction Corporation Ltd." Journal of Scholarly Research, 2015, VOL-3/19

4. Trivedi Shilpa "Performance Review of Gujrat State Road Transport Corporation" International Journal of Social Science \& Interdisciplinary Research Vol.1 Issue 9, September 2012, ISSN 22773630. 